\title{
GCG Role and Audit Quality in Reducing Earnings Management Action in Indonesian Manufacturing Firms
}

\author{
Sigit Handoyo, Windri Bulan Agustianingrum \\ Department of Accounting Faculty of Economics Universitas Islam Indonesia \\ Jl. Ringroad Utara, Condong Catur, Sleman, Yogyakarta, 55283, Indonesia
}

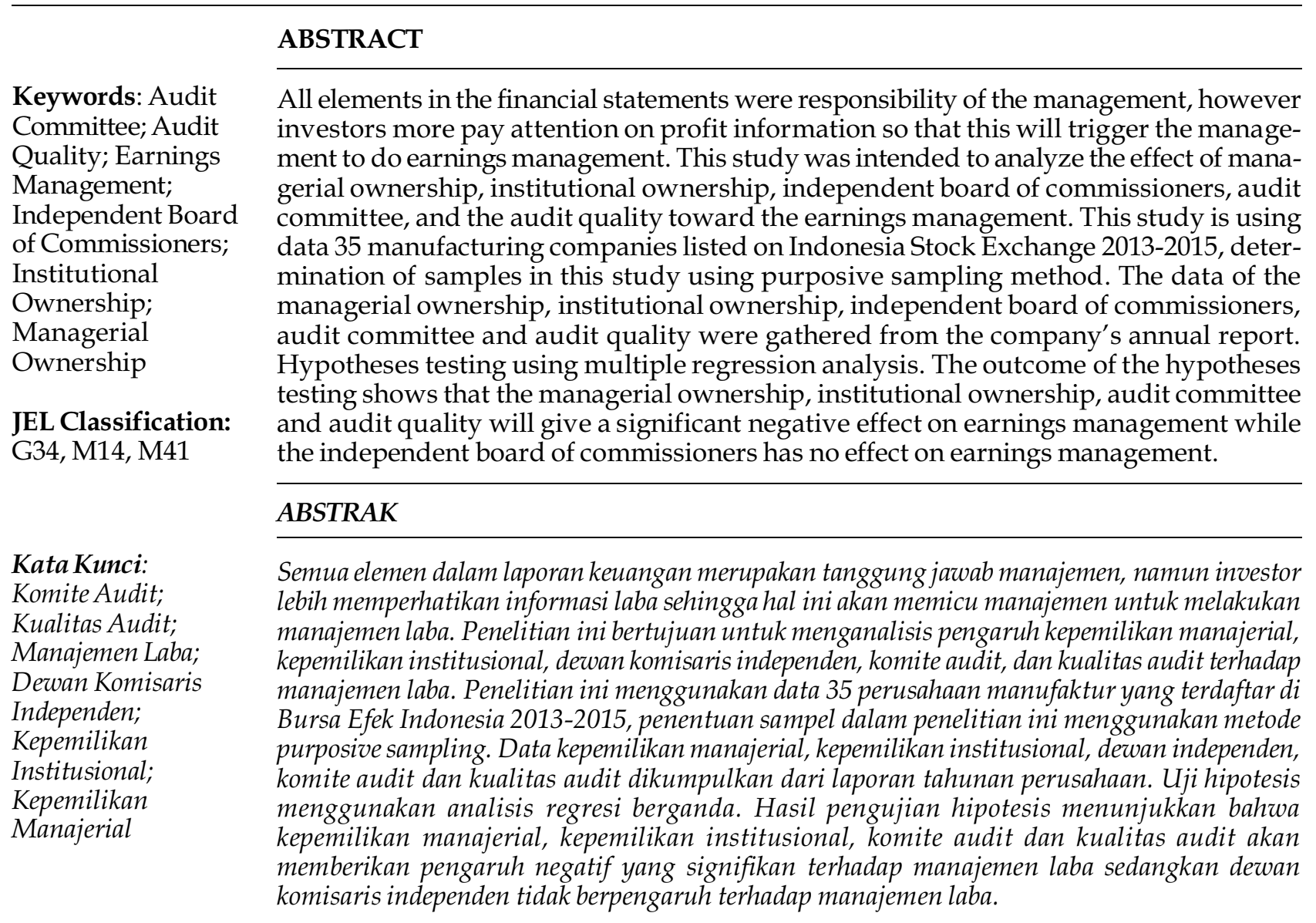

$\triangle$ Corresponding Author:

Sigit Handoyo: +62 274881 546; Fax. +62 274882589

ISSN:2443-2687 (Online)

E-mail: sihando@yahoo.com 


\section{GCG Role and Audit Quality in Reducing Earnings Management Action in Indonesian Manufacturing Firms}

Sigit Handoyo, Windri Bulan Agustianingrum

The financial report is media for presenting a summary of all the financial information in a company that will be communicated to the interested users either internal or external user manual. All elements in the financial statements are the responsibility of management, but the attention of investors is more often focused on the earnings information so that this is what triggers the earnings management by management. According to Agustia (2013) the tendency of external parties to pay more attention to earnings information as a parameter of company performance, will encourage management to manipulate in showing earnings information, called earnings management.

According to agency theory, the separation between owner and manager can cause agency problems. The problem occurs because of misalignment or difference in interest because there is no convergence between the maximum utility company or principal with the manager or the agent is commonly called agency problems (Kusumaningtyas, 2012). With the agency problem, the activity of making the financial report becomes irrelevant to the needs of the company owner.

Agency theory illustrates that earnings management practices can be minimized with the supervision of the internal through good corporate governance (Fanani, 2014). Management profit can be minimized through a monitoring mechanism to reconcile the differences between the interests of owners with management by: (1) enlarge ownership by management; (2) the existence of an institutional stock ownership; (3) through the oversight role of monitoring by independent directors; and (4) establish an audit committee as the company's supervisor.

To increase managerial ownership can be done by providing stock-based compensation to the manager. Management that has a high percentage of share ownership will act as someone who holds interest in the company so that it will suppress the happening of earnings management by management (Mahariana \& Ramantha, 2014).
According to Wahidawati (2001), institutional ownership can be defined as the proportion of shares in circulation held by other institutions outside the company at the end of the year as measured in percentage. Institutional ownership is supposedly capable of providing a supervisory mechanism within the company. The greater the institutional ownership in the company, the lower the tendency of managers perform earnings management activity for their function better supervision of the expert investors. Institutional ownership can reduce the tendency to utilize discretionary management in the financial statements so as to provide the quality of reported earnings.

To create good corporate governance, every company is required to have an independent commissioner (Utami \& Rahmawati, 2008). Pope, Peasnell, \& Young (1998) explains through the role of the board in performing the supervisory function of the company's operations by the management, the composition (proportion) of the board of commissioners can make an effective contribution to the results of the process of preparing the qualified financial statements or the possibility of avoidance of fraudulent financial statements. The greater the proportion of independent commissioners, the less earnings management, which means that the independent commissioner negative effects on earnings management (Nasution \& Setiawan, 2007).

To gain the trust of the users of the financial statements, it is desirable that the quality of the audit is good (Luhgiatno, 2010). High-quality auditing can act as a deterrent to effective earnings management practices because financial statements reflect the reputation of management. If the audit result is not qualified then the reputation of management will be destroyed. The results of the audit conducted by the Big Four accounting firm and non-Big Four can effect the audit qualitys produced. Auditors working in the big four accounting public firms are considered to be of higher quality as they are equipped with a series of train- 


\section{Jurnal Keuangan dan Perbankan | KEUANGAN}

Vol. 21, No. 3, Juli 2017: 436-445

ing and procedures and have audit programs deemed to be more accurate and effective than auditors from the non-Big Four accounting public firms (Guna \& Herawati, 2010).

Research on earnings management has been done in Indonesia some are Nasution \& Setiawan (2007), Guna \& Herawati (2010), Kusumawardhani (2012), Christiani \& Yeterina (2014), Fanani (2014), and Mahariana \& Ramantha (2014), but the results of these studies indicate inconsistency. The purpose of this study was to test back by combining several indicators of earnings management as managerial ownership, institutional ownership, independent board of commissioners, audit committee, and audit quality. Thus, it is hoped that the results will be obtained that can reference and strengthen the results of previous research.

\section{HYPOTHESES DEVELOPMENT}

\section{Managerial Ownership and Earnings Management}

Profit that is less qualified can happen because in running a business company, management is not the owner of the company. This separation of ownership can lead to conflicts in the management that cause managers to act inappropriately with the wishes of the owners. Conflicts resulting from this separation of ownership are called agency conflicts (Kusumawardhani, 2012). How to overcome the agency problem is to increase managerial ownership. To increase managerial ownership can be done in a way to provide stock-based compensation to the manager. Management that has a high percentage of share ownership will act as someone who holds interest in the company so that it will suppress the happening of earnings management by management (Mahariana \& Ramantha, 2014). Based on the description, first hypotheses of this research is:

$\mathrm{H}_{1}$ : managerial ownership has negative effects on earnings management

\section{Institutional Ownership and Earnings management}

According to Wahidawati (2001), institutional ownership can be defined as the proportion of outstanding shares owned by other institutions outside the company, such as banks, insurance companies, investment companies, pension funds, and others at the end of the year as measured in percentages. Institutional ownership is supposedly capable of providing a supervisory mechanism within the company. The greater the institutionally ownership in the company, the lower the tendency of managers perform earnings management activity for their function better supervision of the expert investors. Institutional ownership can reduce the tendency to utilize discretionary management in the financial statements so as to provide the quality of reported earnings. Based on the description, second hypotheses of this research is: $\mathrm{H}_{2}$ : institutional ownership has negative effects on earnings management

\section{Independent Board of Commissioners and Earnings Management}

To create good corporate governance, every company is required to have an independent commissioner (Utami \& Rahmawati, 2008). Pope et al. in Andayani (2010) explains through the role of the board in performing the supervisory function of the company's operations by the management, the composition (proportion) of the board of commissioners can make an effective contribution to the results of the process of preparing the qualified financial statements or the possibility of escaping fraudulent reports finance. The greater the proportion of independent board of commissioners, the less earnings management, which means that the independent board of commissioner negative effects on earnings management (Nasution \& Setiawan, 2007). Based on the description, third hypotheses of this research is: 


\section{GCG Role and Audit Quality in Reducing Earnings Management Action in Indonesian Manufacturing Firms Sigit Handoyo, Windri Bulan Agustianingrum}

$\mathrm{H}_{3}: \quad$ the independent board of commissioners has negative effects on earnings management

\section{Audit Committee and Earnings Management}

Audit committee is considered as a liaison between shareholders and the independent board of commissioners with the management in handling control issues. The audit committee is a committee established by the independent board of commissioners to carry out the task of supervising the management of the company (Nasution \& Setiawan, 2007). The existence of audit committees is useful to ensure transparency, disclosure of financial statements, and equity for all stakeholders so that the existence of the audit committee is very important for the management of the company because it can reduce the occurrence of earnings management. Based on the description, fourth hypotheses of this research is:

$\mathrm{H}_{4}$ : the audit committee has negative effects on earnings management

\section{Audit Quality and Earnings Management}

To gain the trust of the users of the financial statements, it is desirable that the quality of the audit is good (Luhgiatno, 2010). High-quality auditing can act as a deterrent to effective earnings management practices because financial statements reflect the reputation of management. If the audit result is not qualified then the reputation of management will be destroyed. The results of the audit conducted by the Big Four accounting firm and non-Big Four can effect the audit quality produced. Auditors working in the Big Four of public accounting firm are considered to be of higher quality as they are equipped with a series of training and procedures and have audit programs deemed to be more accurate and effective than auditors from the non-Big Four of public accounting firm (Guna \& Herawati, 2010). Based on the description, fifth hypotheses of this research is:

$\mathrm{H}_{5}$ : audit quality has negative effects on earnings management

\section{METHOD}

The population in this research is manufacturing companies listed in Indonesia Stock Exchange in 2013-2015. With certain criteria, selected 35 companies that are used as the final sample in this study as illustrated in Table 1. These criteria are: (1) manufacturing company in IDX which publish financial statements as complete and consistent from year 2013-2015; and (2) manufacturing companies that have data managerial ownership, institutional ownership consistently complete in 2013-2015.

In this research the data used is secondary data. Secondary data needed in this study is the company's financial statements. Secondary data in this study were obtained from the website of Indonesia Stock Exchange is www.idx.co.id. Operational definition and measurement of research variables are presented in Table 2 .

Table 1. Summary of Determination of Number of Samples

\begin{tabular}{lc}
\hline \multicolumn{1}{c}{ Information } & Number of Companies \\
\hline $\begin{array}{l}\text { Manufacturing company in Indonesia Stock Exchange (IDX) which publishes complete } \\
\text { and consistent financial report }\end{array}$ & 146 \\
Manufacturing companies that do not have data managerial ownership, institutional & $(112)$ \\
ownership consistently complete & 35 \\
Sample Research & \\
\hline
\end{tabular}




\section{Jurnal Keuangan dan Perbankan | KEUANGAN}

Vol. 21, No. 3, Juli 2017: 436-445

\section{RESULTS}

Descriptive statistics are used to know the description of research data that is minimum, maximum, mean, and standard deviation. The results of descriptive statistical analysis are presented in Table 3.

Based on Table 3, it can be explained that the mean value earnings management equal to 13.685 , a minimum value of 9.963 , the maximum value of 18.190 , and a standard deviation of 1.571 to the number of observations (n) of 105 . The mean value of the independent board of commissioners approaches the standard deviation of 0.091, thus the deviation of earnings management data is quite high.

Then for mean value managerial ownership of 4.056, a minimum value of $0.00001,180.300$ its maximum value, and a standard deviation of
24.916 by the number of observation (n) of 105 . The mean value of the managerial ownership approaches the standard deviation of 24.916, thus the deviation of managerial ownership data is quite high.

The mean value institutional ownership of 15.860, a minimum value of $0.00001,693.7000$ its maximum value, and a standard deviation of 96.446 by the number of observations (n) of 105 . The mean value of the institutional ownership approaches the standard deviation of 96.446, thus the deviation of institutional ownership data is high.

The mean value independent board of commissioner of 0.364 , a minimum value of 0.200 , the maximum value of 0.7500 , and a standard deviation of 0.091 with a number of observations (n) of 105. The mean value of the independent board of

Table 2. Definition of Operational and Measurement Variable

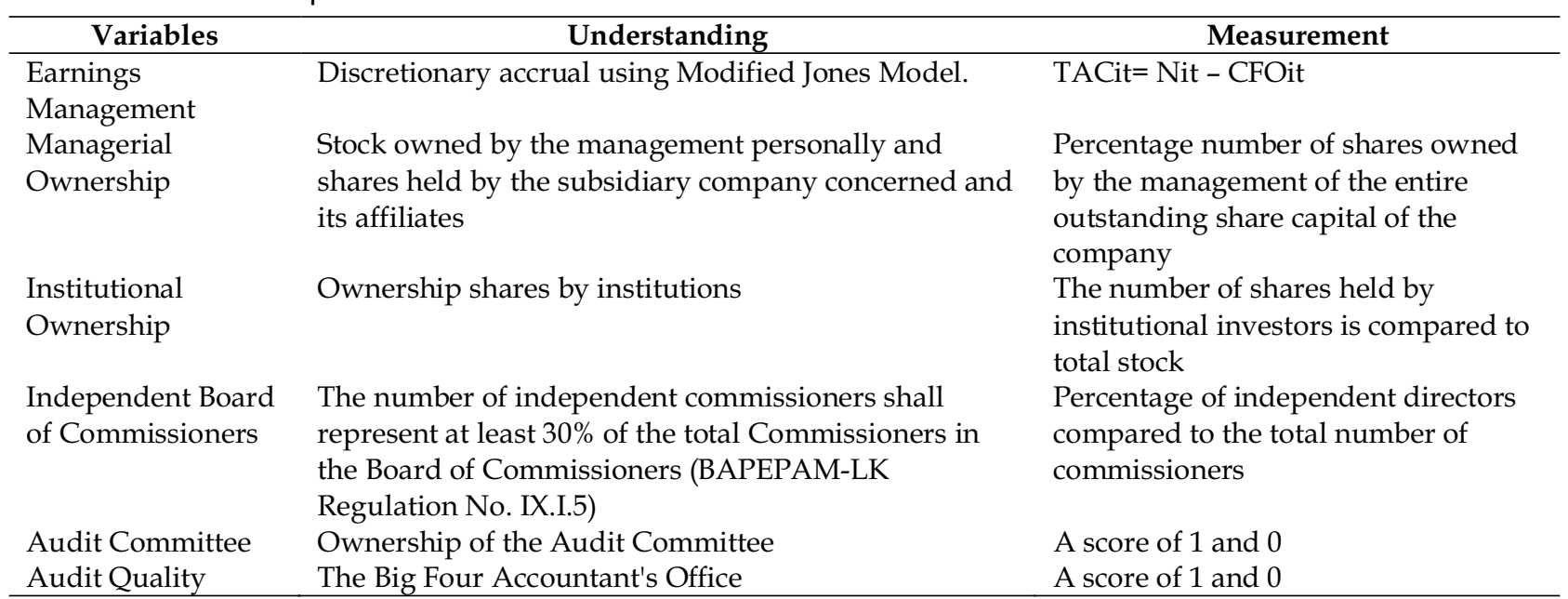

Table 3. Results Descriptive Statistics Variable Research

\begin{tabular}{lrrrr}
\hline \multicolumn{1}{c}{ Variables } & Minimum & Maximum & Mean & \multicolumn{1}{c}{ SD } \\
\hline Earnings management & 9.963 & 18.190 & 13.685 & 1.571 \\
Managerial Ownership & 0.00001 & 180.300 & 4.056 & 24.916 \\
Institutional Ownership & 0.00001 & 693.700 & 15.860 & 96.446 \\
Independent Board of Commissioner & 0.200 & 0.750 & 0.364 & 0.091 \\
Audit Committee & 0 & 1 & 0.970 \\
Audit Quality & 0 & 1 & 0.340 \\
\hline
\end{tabular}




\section{GCG Role and Audit Quality in Reducing Earnings Management Action in Indonesian Manufacturing Firms}

Sigit Handoyo, Windri Bulan Agustianingrum

commissioners approaches the standard deviation of 0.091 , thus the deviation of independent board of commissioner data is low.

The mean value of the audit committee of 0.97 , the minimum value is 0 , the maximum value of 1 , and standard deviation of 0.167 with the total number of observations (n) of 105. The mean value of the audit committee approaches the standard deviation of 0.167 , thus the deviation of audit committee data is low.

The mean value of the audit quality of 0.34 , the minimum value is 0 , the maximum value of 1 , and standard deviation of 0.477 with the total number of observations (n) of 105 . The mean value of audit quality approaches the standard deviation of 0.477 , thus the deviation of audit quality data is low.
The results of classical assumptions in Table 4 shows that this research has been free from the problem of normality $(0.706>0.05)$, multicollinearity (VIF five variables $<10$ ), heteroscedasticity (fifth variable probability value $>0.05$ ), and autocorrelation (value $\mathrm{dL}=1.571$ and $\mathrm{dU}=1.780$ so that $4-\mathrm{dU}=4-1.780=2.220$, and $4-\mathrm{dL}=4-1.571=$ 2.429. So $1.780<1.785<2.220$ ). So the test model has been free from the problem of testing the classical assumption.

The results of multiple linear regression in Table 5 show that managerial ownership has a negative and significant effect on earnings management, with a significance value of 0.046 which is less than 0.005 . This means, if the managerial ownership increases, then the earnings management will decrease.

Table 4. The Testing of Classical Assumption

\begin{tabular}{|c|c|c|c|c|c|}
\hline \multirow[b]{2}{*}{ Normality } & \multirow[b]{2}{*}{ Variables } & \multicolumn{2}{|c|}{ Multicolinearity } & \multirow[b]{2}{*}{ Heteroscedasticity } & \multirow{2}{*}{$\begin{array}{c}\text { Autocorrelation } \\
\text { (Durbin-Watson) }\end{array}$} \\
\hline & & $\begin{array}{c}\text { Critical } \\
\text { Value }\end{array}$ & VIF & & \\
\hline \multirow[t]{5}{*}{0.706} & Managerial Ownership & 10 & 3.625 & 0.938 & 1.785 \\
\hline & Institutional Ownership & 10 & 3.033 & 0.992 & \\
\hline & $\begin{array}{l}\text { Independent Board of } \\
\text { Commissioners }\end{array}$ & 10 & 1.147 & 0.061 & \\
\hline & Audit Committee & 10 & 1.248 & 0.152 & \\
\hline & Audit Quality & 10 & 1.109 & 0.995 & \\
\hline
\end{tabular}

Table 5. The Testing of Multiple Regression Analysis

\begin{tabular}{|c|c|c|c|c|}
\hline Variables & $\begin{array}{l}\text { Regression } \\
\text { Coefficient }\end{array}$ & $\begin{array}{l}\text { Standard } \\
\text { Error }\end{array}$ & t-statistics & Sig. \\
\hline Constants & 10,453 & 1,054 & 9,915 & 0,000 \\
\hline Managerial Ownership & -0.210 & 0.108 & -1.942 & 0.046 \\
\hline Institutional Ownership & -0.057 & 0.028 & -2.033 & 0.045 \\
\hline Independent Board of Commissioners & -1.545 & 1.701 & -0.908 & 0.366 \\
\hline Audit Committee & -2.398 & 0.971 & -2.471 & 0.015 \\
\hline Audit Quality & -0.848 & 0.321 & -2.639 & 0.010 \\
\hline $\begin{array}{l}\mathrm{R}^{2}: 0.152 \\
\text { Adj. } \mathrm{R}^{2}: 0.109 \\
\text { F-statistical: } 3.538 . \mathrm{Sig}=0.000 \text {. } \\
\text { DW-statistical: } 1.785 \\
\mathrm{n}: 105\end{array}$ & & & & \\
\hline
\end{tabular}




\section{Jurnal Keuangan dan Perbankan | KEUANGAN}

Vol. 21, No. 3, Juli 2017: 436-445

The results of multiple linear regression shows that institutional ownership has a negative and significant effect on earnings management, with a significance value of 0.045 which is less than 0.05. This means, if the institutional ownership increases, then the earnings management will decrease.

The results of multiple linear regression relating to the independent board of commissioners has no significant effect on earnings management, which is indicated by a significance value of 0.366 which is greater than 0.05 . This means, if the independent board of commissioners increases, then the earnings management will remain or constant.

The results of multiple linear regression shows that the audit committee has a negative and significant effect on earnings management, with a significance value of 0.015 which is less than 0.05 . This means, if the audit committee increases, then the earnings management will decrease.

The results of multiple linear regression shows that the audit quality has a negative and significant effect on earnings management with a significance value of 0.010 which is less than 0.05 . This means that, if the audit quality increases, then the earnings management will decrease.

\section{DISCUSSION}

\section{The Effect of Managerial Ownership on Earnings Management}

Managerial ownership has a negative and significant effect on earnings management. These results are consistent with the findings of research Mahariana \& Ramantha (2014) and Fanani (2014) who also found a negative effect of managerial ownership on earnings management.

Profit that is less qualified can happen because in running a business company, management is not the owner of the company. This separation of ownership can lead to conflicts in the company management that cause managers to act inappro- priately with the wishes of the owners. Conflicts resulting from this separation of ownership are called agency conflicts. Imagery of interests between owners and management occurs when two parties want to maximize their own wealth (Kusumawardhani, 2012). Some of the mechanisms that can be used to overcome such agency problems are by increasing managerial ownership (Jensen \& Meckling, 1976). To improve the managerial ownership can be done in a way to give stock-based compensation (stock-based compensation) to the manager. Stock-based compensation to managers results in an increase in managerial ownership. The management that has a high percentage of share ownership will act as someone who holds an interest in the company. Thus, it is likely that the level of managerial ownership will be in the same direction to suppress earnings management by management (Mahariana \& Ramantha, 2014). With so expected managers will act in accordance with the wishes of the principal as a manager will be motivated to improve his performance.

\section{The Effect of Institutional Ownership on Earnings Management}

Institutional ownership has a negative and significant effect on earnings management. Institutional ownership is supposedly capable of providing a supervisory mechanism within the company. The greater the institutional ownership in the company, the lower the tendency of managers perform earnings management activity for their supervisory function better than investors who sophisticated (sophisticated investors). The results of this study support of research conducted by Fanani (2014).

According Kusumawardhani (2012), institutional ownership has the ability to control the management through an effective monitoring process so as to reduce earnings management. The percentage of certain shares owned by the institu- 


\section{GCG Role and Audit Quality in Reducing Earnings Management Action in Indonesian Manufacturing Firms}

Sigit Handoyo, Windri Bulan Agustianingrum

tion can effect the process of preparing financial statements that do not rule out the existence of accrualization according to the interests of the management. Institutional ownership can reduce the tendency to utilize discretionary management in the financial statements so as to provide the quality of reported earnings.

\section{The Effect of Independent Board of Commissioners on Earnings Management}

The independent board of commissioners has no significant effect on earnings management. Similar results were found by Guna \& Herawati (2010) which also shows that the existence of independent commissioners within the company failed to become one of the good corporate governance mechanisms in detecting earnings management.

According to Agustia (2013) the size of the independent board of commissioners is not a major determinant of the effectiveness of oversight of corporate management. However, the effectiveness of the control mechanism depends on the values, norms, and beliefs received in an organization and the role of independent board of commissioners in the monitoring activities of management.

The active role of the independent board of commissioners in practice is highly dependent on the environment created by the company concerned. In some cases, it is good that the independent board of commissioners play a relatively passive role, but in Indonesia it is often the case that members of the independent board of commissioners do not even exercise their fundamental supervisory role towards the board of directors. The independent board of commissioners is often considered to have no benefits. This can be seen in the fact, that many members of the independent board of commissioners do not have the ability and cannot demonstrate its independence. So that in many cases the board also failed to represent the interests of other stakehold- ers than the interests of the majority shareholder (FCGI, 2000).

The ownership of a centralized share in one group or one family may be one of the reasons for the weakness of the independent board of commissioners position, since the appointment of the members of the independent board of commissioners is given as a sense of respect only or based on family relations or close acquaintance. In Indonesia, a former government official or an active member is usually appointed as a member of the independent board of commissioners of a company in order to have access to the relevant government agency. In this case, the integrity and capacity of the independent board of commissioners often becomes less important. In turn, the independence of the board of commissioners to be very doubtful because of his special relationship with the majority shareholder or his relationship with the board of directors along with a lack of integrity and the ability of the independent board of commissioners (FCGI, 2000).

\section{The Effect of Audit Committee on Earnings Management}

Audit Committee has a negative and significant effect on earnings management. The results in accordance with the research by Nasution \& Setiawan (2007) which states that the audit committee has a negative effect on earnings management. The audit committee is a committee established by the board of commissioners to carry out the task of supervising the management of the company (Nasution \& Setiawan, 2007). The existence of audit committees is useful to ensure transparency, disclosure of financial statements, and equity for all stakeholders. Audit committee is a new component in the company's control system. In addition, the audit committee is considered as a liaison between shareholders and the board of commissioners with the management in handling control issues. Therefore, the existence of the au- 
dit committee is very important for the management of the company and can reduce the level of earnings management.

\section{The Effect of Audit Quality on Earnings Management}

Audit quality has a negative and significant effect on earnings management. The results are consistent with the research by Guna \& Herawati (2010) which states that audit quality experience been influenced to earnings management. To gain the trust of the users of the financial statements, it is desirable that the quality of the audit is good (Luhgiatno, 2010). Christiani \& Yeterina (2014) states that high-quality auditing acts as an effective deterrent earnings management because management reputation will be destroyed and the company's value will drop if this false reporting detected and exposed. Ratmono (2010) states that qualified auditors are able to detect earnings management actions undertaken by the client.

Christiani \& Yeterina (2014) describes the audit service is a monitoring tool against the possibility of a conflict of interest between owners and managers as well as between the shareholders by the number of different ownership. Audit services can reduce the information asymmetry between managers and stakeholders of the company by allowing outsiders to check the validity of the financial statements. The results of the audit conducted by the Big Four accounting firm and non-Big Four effects the audit qualitys produced. Auditors working in KAP Big Four are considered higher quality because the auditor is provided by a series of training and auditing procedures and programs that are considered more accurate and effective than the auditors of the KAP non-Big Four (Guna \& Herawati, 2010).

\section{CONCLUSION AND SUGGESTIONS}

\section{Conclusion}

Based on the results of the previous analysis and discussion, it can be concluded that managerial ownership, institutional ownership, audit committee, and audit quality proved to have a significant effect on earnings management, while the independent board of commissioners had no significant effect on earnings management. This shows the weakness of the role and presence of independent board of commissioners as executive oversight functions at manufacturing companies in Indonesia. So, the presence of independent directors in the company failing to become one of the mechanisms of good corporate governance in detecting earnings management. As an implication of the results of this study the investors are required to better know the quality of the independent board of commissioners of companies where they invest their shares.

\section{Suggestions}

Earnings management can reflect the higher the weakness or ability of the company in the market competition, so it is expected the company make a positive issue, improvement of company management, which makes investors interested in investing in order to increase capital and ultimately implicate the decline in earnings management action.

Managerial ownership, institutional ownership, independent board of commissioners, audit committee, and audit quality need to be noticed by the company, as this aspect in addition to providing a great appeal to investors who will invest funds in the company.

For investors, earnings management can serve as the basis for investment decision making 


\section{GCG Role and Audit Quality in Reducing Earnings Management Action in Indonesian Manufacturing Firms}

Sigit Handoyo, Windri Bulan Agustianingrum

because this aspect measures the company's ability to generate profit levels of the investments made to the company.

For further research can use or add other external factors outside the model such as the level of leverage and the change of auditor as an independent variable that can effect earnings management.

\section{REFERENCES}

Agustia, D. 2013. Pengaruh Faktor Good Corporate Governance, Free Cash Flow, dan Leverage terhadap Manajemen Laba. Jurnal Akuntansi dan Keuangan, 15(1): 27-42.

Andayani, T.D. 2010. Pengaruh Karakteristik Dewan Komisaris Independen terhadap Manajemen Laba (Studi pada Perusahaan Manufaktur yang Terdaftar di Bursa Efek Indonesia). Thesis. Diponegoro University.

Christiani, I. \& Yeterina, W.N. 2014. Pengaruh Kualitas Audit terhadap Manajemen Laba. Jurnal Akuntansi dan Keuangan, 16(1): 52-62.

Fanani, Z. 2014. Karakteristik Perusahaan dan Corporate Governance terhadap Manajemen Laba. Jurnal Keuangan dan Perbankan, 18(2): 181-200.

Forum Corporate Governance Indonesia (FCGI). (2000). Peranan Dewan Komisaris dan Komite Audit dalam Pelaksanaan Corporate Governance. http:// www.fcgi.or.id

Guna, W.I. \& Herawati, A. 2010. Pengaruh Mekanisme Good Corporate Governance, Independensi Auditor, Kualitas Audit, dan Faktor Lainnya terhadap Manajemen Laba. Jurnal Bisnis dan Akuntansi, 12(1): 53-68.

Jensen, M.C. \& Meckling, W.H. 1976. Theory of Firm: Managerial Behavior, Agency Cost, and Ownership Structure. Journal of Financial Economics, 3(4): 305-360.
Kusumaningtyas, M. 2012. Pengaruh Independensi Komite Audit dan Kepemilikan Institusional terhadap Manajemen Laba. Prestasi, 9(1): 41-61.

Kusumawardhani, I. 2012. Pengaruh Corporate Governance, Struktur Kepemilikan, dan Ukuran Perusahaan terhadap Manajemen Laba. Jurnal Akuntansi dan Sistem Teknologi Informasi, 9(1): 4154 .

Luhgiatno. 2010. Analisis Pengaruh Kualitas Audit terhadap Manajemen Laba (Studi pada Perusahaan yang Melakukan IPO di Indonesia). Fokus Ekonomi, 5(2): 15-31.

Mahariana, I.D.G.P. \& Ramantha, I.W. 2014. Pengaruh Kepemilikan Manajerial dan Kepemilikan Institusional pada Manajemen Laba Perusahaan Manufaktur di Bursa Efek Indonesia. E-Jurnal Akuntansi Universitas Udayana, 7(2): 519-528.

Nasution, M. \& Setiawan, D. 2007. Pengaruh Corporate Governance terhadap Manajemen Laba di Industri Perbankan Indonesia. Simposium Nasional Akuntansi X Makassar.

Pope, P.F., Peasnell, K.V., \& Young, S. 1998. Outside Directors, Board Effectiveness, and Earnings Management. Working Paper. Lancaster University.

Ratmono, D. 2010. Manajemen Laba Riil dan Berbasis Akrual: Dapatkah Auditor yang Berkualitas Mendeteksinya? Simposium Nasional Akuntansi XIII Purwokerto 2010.

Utami, R.B. \& Rahmawati. 2008. Pengaruh Komposisi Dewan Komisaris dan Komite Audit pada Aktivitas Manajemen Laba pada Perusahaan Manufaktur yang Terdaftar di Bursa Efek Indonesia. Prosiding Seminar Ketahanan Ekonomi Nasional (SKEN) Yogyakarta.

Wahidawati. 2001. Pengaruh Kepemilikan Manajerial dan Kepemilikan Institusional pada Kebijakan Hutang Perusahaan: Sebuah Perspektif Theory Agency. Jurnal Riset Akuntansi Indonesia, 5(1). 